\title{
Three Mid-1800s Caddo Vessels from the Brazos Reserve
}

Timothy K. Perttula

Heritage Research Center, Stephen F. Austin State University

Follow this and additional works at: https://scholarworks.sfasu.edu/ita

Part of the American Material Culture Commons, Archaeological Anthropology Commons, Environmental Studies Commons, Other American Studies Commons, Other Arts and Humanities Commons, Other History of Art, Architecture, and Archaeology Commons, and the United States History Commons

Tell us how this article helped you.

This Article is brought to you for free and open access by the Center for Regional Heritage Research at SFA ScholarWorks. It has been accepted for inclusion in Index of Texas Archaeology: Open Access Gray Literature from the Lone Star State by an authorized editor of SFA ScholarWorks. For more information, please contact cdsscholarworks@sfasu.edu. 


\section{Three Mid-1800s Caddo Vessels from the Brazos Reserve \\ Creative Commons License \\ (c) $($ ) $(9)$}

This work is licensed under a Creative Commons Attribution-NonCommercial 4.0 International License 


\title{
THREE MID-1800S CADDO VESSELS FROM THE BRAZOS RESERVE
}

\author{
Timothy K. Perttula
}

\section{INTRODUCTION}

Although a considerable body of historic archival and documentary information is available on the Caddo Indian peoples that lived in Texas between ca. 1836 and 1859-the removal period (see Carter 1995; La Vere 1998; Perttula and Bruseth 1998; Smith 1995, 1996; Swanton 1942)--not much archaeological evidence has been uncovered for their settlements (Early 2000; Parsons et al. 1999; Perttula 1992). By the latc 1830s and early $1840 \mathrm{~s}$, most of the Caddo groups had been removed from Northeast Texas as their traditional homelands were taken and settled by Anglo-American farmers and planters. Instead, they took up residence in Oklahoma, or settled with other affiliated groups (such as the Delaware, Cherokee, and others) on the Brazos River in north central Texas. There they continued to farm and hunt bison, even after they had been placed on the Brazos Reserve (in prescnt-day Young County, Texas) in 1854. The Caddo peoples on the Reserve, about 1050 in number, were removed in August 1859 to the Indian Territory and the Wichita agency in western Oklahoma.

In this paper, I discuss three ceramic vesscls in the collections of the Brooklyn Museum in New York City. They were apparently collected in the mid-1850s from the Caddo peoples living on the Brazos Reserve. As such, the vessels provide a unique record and look at the kinds of ceramic vessels being manufactured by the Caddo immediately before they wcrc removed to Oklahoma, and has considerable cultural and archaeological significance.

\section{VESSELS FROM THE BROOKLYN MUSEUM}

Three decorated vessels in the Brooklyn Museum were apparcntly collected from the Brazos Reserve by a Dr. Nathan Sturges Jarvis in the 1850 s. Jarvis was a medical doctor, and had served in Texas on the staff of General Zachary Taylor during the 18461848 Mexican-American War. How Dr. Sturges came by the vessels is not known, nor is it known what he was doing in the Brazos Reserve area in the 1850s.

All three vessels are globular jars or small-mouthed bottles, with squat and undecorated rims, and they are decorated with a variety of engraved elements. Their temper or paste are not known, nor is any information availablc on how they were fired. A somewhat similar vessel shape is reported the late 18th Indian Springs site (41BW512) on the Red River (Perttula n.d.), and from the Fish Hatchery sitc in Natchitoches, Louisiana (Walker 1935:Figure 2b).

The first vessel (Figure 1, Brooklyn Museum No. 50.67.105A) has three horizontal panels that extend from below the lip to near the basc, and these panels are filled with cross-hatched elements. The upper and lower panels have rectangular cross-hatched elements, whilc the middle panel has an alternating series of cross-hatched pendant triangles (Figure 1).

The second vessel (Brooklyn Museum No. 50.67.105B) has a broad, diagonallyfilled and undulating scroll on the lower body. Corresponding undulating engraved lines 


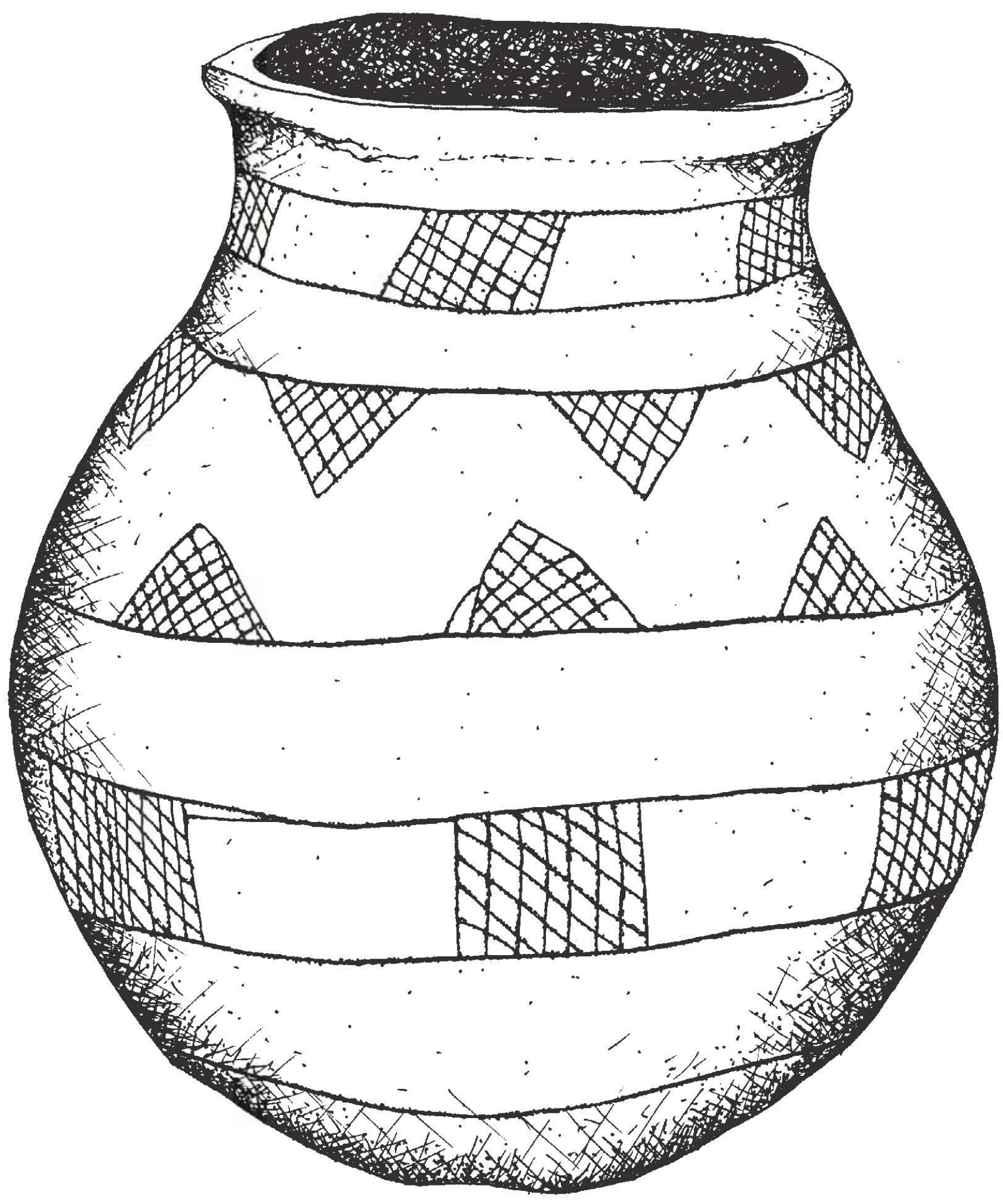

Figure 1. Vessel 50.67.105A, Brooklyn Museum. 


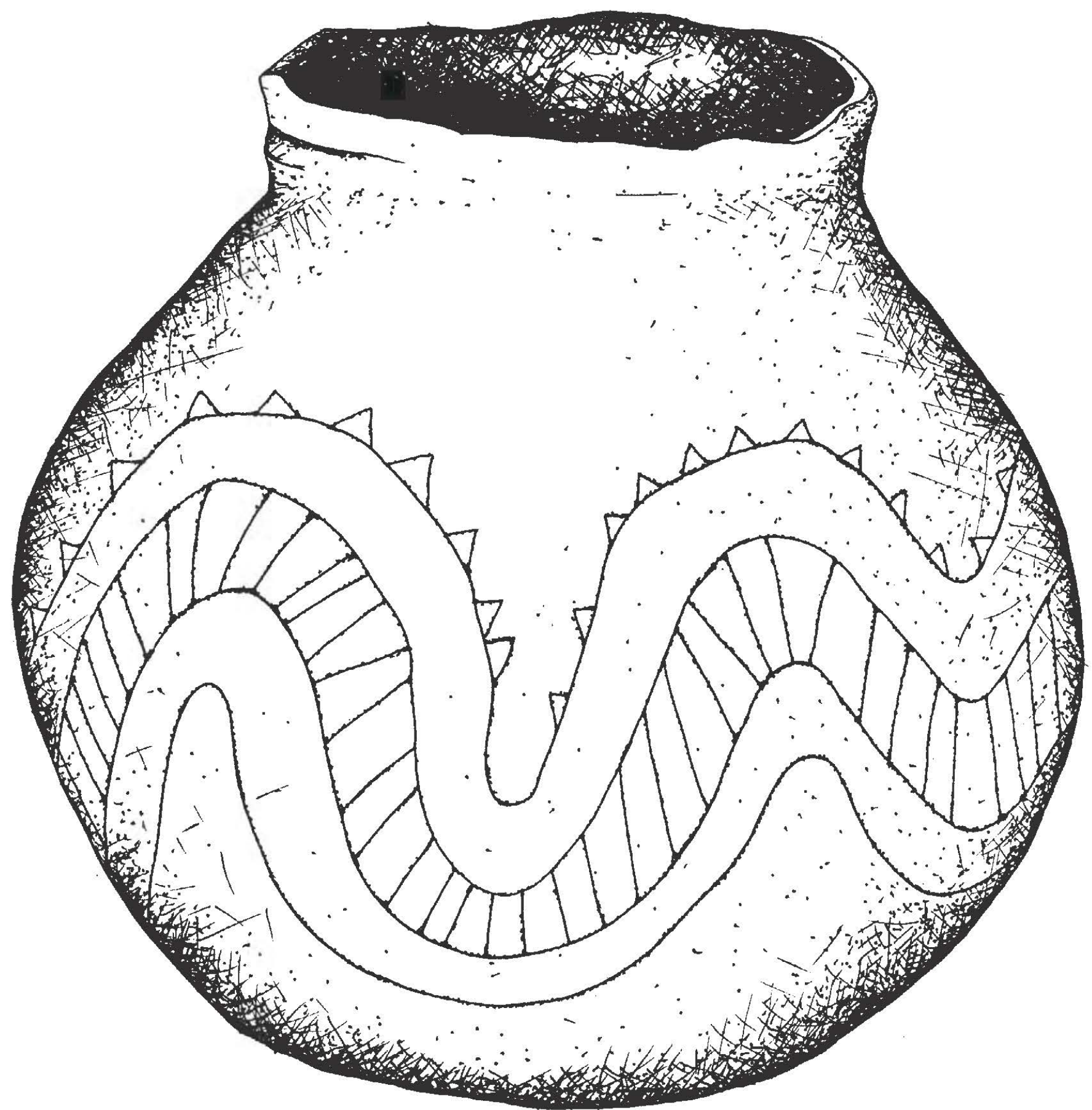

Figure 2. Vessel 50.67.105B, Brooklyn Museum. 


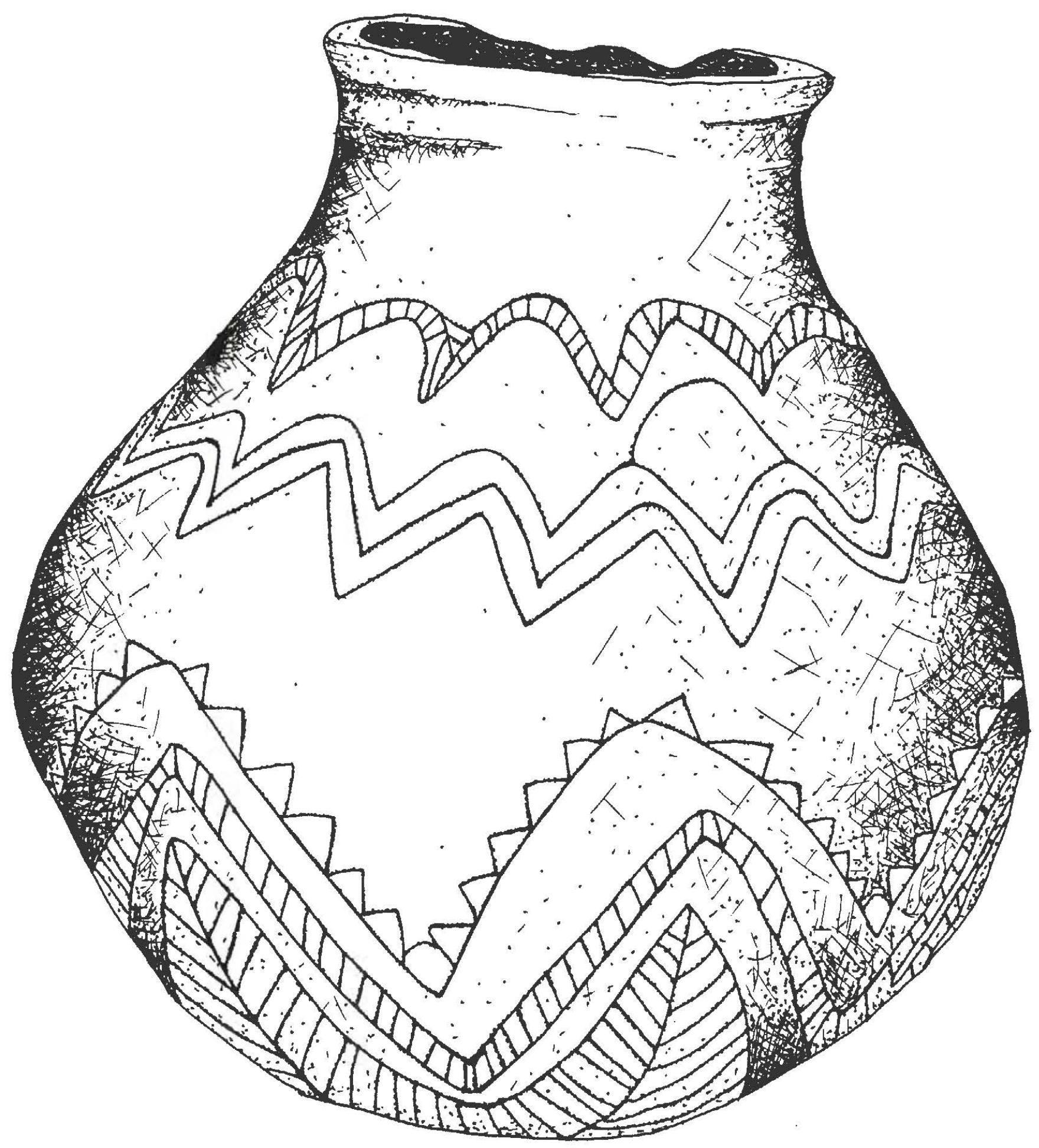

Figure 3. Vessel 50.67.105C, Brooklyn Museum. 
were placed above and below the scroll, and the uppermost line has a series of small but unfilled pendant triangles (Figure 2).

The last vessel (Brooklyn Museum No. 50.67.105C) has a very complicated engraved design on the vessel body; the rim is plain (Figure 3). The engraved design is characterized by a series of narrow scrolls, with several filled with diagonal lines, and another composed of three closely-spaced and undulating lines. Above one of the diagonal line-filled scrolls is a corresponding undulating engraved line with a series of unfilled pendant triangles.

\section{CULTURAL AND ARCHAEOLOGICAL SIGNIFICANCE OF THE VESSELS}

To my knowledge, no other Caddo Indian vessels are currently known or documented that were made in the mid-1850s, or come from the Brazos Reserve arca. The form and decorative style of the vessels are immediately recognizable as Caddo in origin, and the fact that they were made in the 1850s demonstrates that there were Caddo potters still producing traditional pottery at that time; the mid-19th century archaeological record is silent on the retention of this craft among the Caddo peoples. Furthermore, the manufacture and use of engraved finewares--with distinctive pendant triangular, scroll, and snake-like motifs--remained an important part of the material culture of the Caddo Indian groups living on the Brazos River, particularly the Kadohadacho groups.

\section{ACKNOWLEDGMENTS}

I would like to thank Stacey Halfmoon for providing me copies of the photographs of the three vessels from the Brooklyn Museum, and I appreciate Mark Parsons for providing ine with a draft copy of his report on the Timber Hill site. Finally, Nancy Reese provided the drawings of the vessels used in this paper.

\section{REFERENCES CITED}

Carter, C. E.

1995 Caddo Indians: Where We Come From. University of Oklahoma Press, Norman.

Farly, A. M.

2000 The Caddos of the Trans-Mississippi South. In Indians of the Greater Southeast: Historical Archaeology and Ethnohistory, edited by B. G. McEwan, pp. 122-141. University Press of Florida, Gainesville.

La Vere, D. L.

1998 The Caddo Chiefdoms: Caddo Economics and Politics, 700-I835. University of Nebraska Press, Lincoln.

Parsons, M. L., J. E. Bruseth, J. Bagur, and C. McCrocklin

1999 Finding Sha'chahdinnih (Timber Hill), the Last Village of the Kadohadacho in the Caddo Homeland. MS on file, Archeology Division, Texas Historical Commission, Austin. 
Perttula, T. K.

1992 "The Caddo Nation": Archaeological and Ethnohistoric Perspectives. University of Texas Press, Austin.

n.d. The Indian Springs Site (41BW512), a late 18th Century Kadohadacho Settlement on the Red River in Northeastern Texas. MS in preparation.

Perttula, T. K. and J. E. Bruseth (editors)

1998 The Native History of the Caddo: Their Place in Southeastern Archeology and Ethnohistory. Studies in Archeology 30. Texas Archeological Research laboratory, The University of Texas at Austin.

Smith, F. T.

1995 The Caddo Indians: Tribes at the Convergence of Empires, 1542-1854. Texas A\&M University Press, College Station.

1996 The Wichita and Caddo Indians: Relations with the U.S., 1846-1901. Texas A\&M University Press, College Station.

Swanton, J. R.

1942 Source Materialon the History and Ethnology of the Caddo Indians. Bulletin 132. Bureau of American Ethnology, Smithsonian Institution, Washington, D.C.

Walker, W. M.

1935 A Caddo Burial Site at Natchitoches, Louisiana. Smithsonian Miscellaneous Collections, Vol. 94, No. 14. Smithsonian Institution, Washington, D.C. 